age of 25 years are estimated by Dr. Penrose as about 1 in 6,000 .

Other influences related to changes in intelligence level and discussed by Dr. Penrose are birth-rates in rural and urban populations. Fertility is higher in rural than in urban areas, and the average intelligence is generally found to be much lower in the country than in the towns. Actual mental deficiency is also found more frequently in rural than in urban districts. The main cause would presumably be the migrations of the more able people from the country to the town, where industrial development offers them greater economic inducement than is found in agricultural areas. An additional factor in the decline of fertility among certain classes has frequently been stressed. This is the high cost of education and general high standard of living. Yet another factor is the employment of women, usually the more intelligent ones, in industry and commerce.

Whatever effects social selection has upon the level and distribution of intelligence, it certainly seems to have favourable effects upon physique. Besides a marked reduction in the incidence of diseases like tuberculosis, a notable increase has taken place in the average height and weight of working-class school children. As regards the question of intelligence as an inheritable character, Dr. Penrose inclines to the view that the presence of a favourable environment may make a significant difference to the scores made on an intelligence test.

Dr. Penrose leaves open the possibility of an T.Q. of 90 becoming normal with an improved environ. ment. Some psychologists would consider this as somewhat too high an estimate of the possible effects of environment upon the scores of an intelligence test. He concludes that "on account of social selection, the intelligence level of the general community tends to move towards the point at which fertility is highest". He takes, however, a more moderate view of the point of highest fertility than other writers and regards it as lying in the region of 90 (Binet I.Q.). In his view the "fecundity of the mentally defective is largely mythical" and those with an I.Q. below 70 have a fertility about one quarter of the normal.

Finally, Dr. Penrose is inclined to believe that the most immediate causes of differential fertility and also of general trends in birth-rate are probably psychological in nature. In this connexion it might be worth mentioning that a very recent investigation of Prof. L. M. Terman on marriage revealed that orgasm inadequacy was present in one third of the women in his large sample. His analysis suggests that this inadequacy may be largely genetic in origin. J. I. COHEN.

\title{
Protection of the Fauna and Flora of Africa
}

$\mathrm{T}$ HE "Final Act" of the Second International Conference for the Protection of the Fauna and Flora of Africa held in London in May last has now been issued.* The Conference was held under the chairmanship of the Earl of Onslow, and was attended by delegates of the following Governments : Union of South Africa, Belgium, Great Britain and Northern Ireland, Egypt, France, Italy, Portugal and the Netherlands. The interests of the Anglo-Egyptian Sudan were represented by the United Kingdom and Egyptian delegations jointly.

The delegates met, at the invitation of the Government of the United Kingdom of Great Britain and Northern Ireland, on May 17-24, the invitation having been issued in accordance with the terms of the protocol which formed part of the agreements concluded at the International Conference for the Protection of the Fauna and Flora of Africa, held in London in 1933. The Conference had before it a number of statements which had been circulated by delegations on behalf of the Governments represented, setting out the measures which had been taken in their territories to give effect to the provisions of the Convention.

The Act sets forth the names of the delegates and advisers of each Government represented, and a list of the committee of experts appointed to make suggestions for the addition of further species to the Annex to the Convention on the occasion of its next revision. Great Britain was represented by the Right. Hon. the Earl of Onslow, Sir William F. Gowers, Mr. E. B. Bowyer and Mr. B. F. Wright as delegates, and by Mr. T. Hoskyns Abrahall, Captain Keith F. T. Caldwell, Mr. B. Cockram,

- Second International Conference for the Protection of the Fauna and Flora of Africa, London, May 1938. Final Act. Pp. 149. (London H.M. Stationery Office, 1938.) 28. 6d. net.
Captain J. G. Dollman, Mr. J. M. Ellis, Mr. G. G. Fitzmaurice, Dr. C. Forster-Cooper, Mr. Hugh Fraser, Sir Arthur W. Hill, Mr. L. W. N. Homan, Dr. Julian S. Huxley, Dr. P. R. Lowe, Sir Guy A. K. Marshall, Sir Peter Chalmers Mitchell, Mr. A. H. Stocks, and Mr. M. J. R. Talbot as advisers. The secretary-general was Mr. Francis Hemming, and the secretary, Mr. D. H. F. Rickett. It also reports the statements made by the various delegates, who briefly outlined the measures taken by their various Governments to give effect to the provisions of the Convention.

The Act is followed by eight annexes : (1) dealing with the report of the Committee of Experts relating to the species of mammals, birds and plants recommended for inclusion in the Annex to the Convention on the occasion of its next revision (pp. 38-69), and (2) memoranda submitted by the various Governments on the action taken by them to give effect to the provisions of the Convention (pp. 70-149).

The memorandum submitted by the Belgian Government (pp. 72-73) is followed by several enclosures (pp. 74-127) in which is set forth a full and complete exposé of a decree of April 21, 1937, on "La Chasse et La Peche au Congo Belge", and a discussion of every article governing that decree and the motives which have suggested them. It is a very valuable contribution to the subject of international conservation of faunas and floras.

From the scientific, economic and biological points of view, the importance of the two African conferences which have already been held can scarcely be exaggerated, in that for the first time in history concerted international efforts have been made to ensure the preservation of the fauna and flora of an entire continent before it is too late. 
For the first time in the history of the world, delegates of, and advisers to, the various Governments concerned have met together in council, armed with the knowledge and experience of the disastrous results which may follow the uncontrolled actions of blundering and profiteering man, in order to devise reciprocal measures designed to prevent such actions in the future and to conserve for all time, in so far as it is possible, the natural features and economic possibilities of a great continent.

It is true that as yet only the most elementary steps have been taken, but the important point is that a beginning has been made and definite steps in the right direction taken. Doubtless as more conferences are held, the necessity for enlarging the scope of the term 'flora' will be realized, until it comprehends the consideration of the far wider question of the preservation of the balance not only between forested and unforested areas, but also of the proper conservation of those essontial areas which act like sponges for the storage of water and control the water supply of those areas of land which can be properly utilized for agricultural purposes.

In this connexion, the deliberations and actions of future conferences will surely profit by the gross mistakes which were originally made in developing the agricultural resources of such countries as the United States of America, Australia and New Zealand. In America, for example, we now know that as a consequence of ignorant and thoughtless drainage schomos, thousands of square miles of good land have literally 'gone with the wind'; while in Australia the over-zealous clearing away of forested areas has upset the biological balance of Nature, with the inevitable and consequential appearance of various plagues of an animal or vegetable nature which may, and have, cost millions of good money to combat. We would venture, therefore, to make the suggestion that the work of future conferences would be enormously benefited and its scope very profitably enlarged by the inclusion in its general body of national advisers of a sufficiency of forestry experts.

PERCY R. LOWE.

\section{The Morphology of the Carpel}

A $\mathrm{N}$ important contribution to the vexed question of carpel morphology has recently been published in La Cellule $(47,287-452$; 1938) by Prof. V. Grégoire, the late professor of botany at the University of Louvain (see NATURE, 143, 400 ; 1939); it is characterized by the remarkable number of fine illustrations, mainly photomicrographs (no fewer than 252 in fourteen plates). The problem is approached from the point of view of development, and it is more than a coincidence that both Prof. McLean Thompson, of the University of Liverpool, and Prof. Grégoire, approaching it from this angle, reject decisively the classical theory that the carpel may be regarded as a modified leaf. The "state of flowering" of McLean Thompson and the "reproductive apex" of Grégoire necessitate a new terminology to interpret their characteristics of form, as both authors are agreed that analogies from vegetative organizations are misleading and quite unjustified.

We owe to previous papers by Prof. Grégoire and his colleagues the concept of the vegetative growth apex as establishing, in successive time intervals, or plastochrones, a series of transversely expanded foundations, which are components of the axis (the soubassements), upon which are then raised new foliar primordia. This mode of growth necessitates a meristem organized in depth and constructed, in modern terminology, of a tunica overlying a corpus, both of which have a meristematic nature and contributo to these succossive units of shoot organization.

Prof. Grégoire points out that noithor tunica nor corpus can be identified at the reproductive apex. There is a superficial meristem of uncertain depth, covering both the summit and the flanks of the apex; but this is not identified as a tunica because of the frequency with which periclinal divisions alternate with anticlinal, thus adding to the depth of parenchyma below. Below it there is no meristematic corpus at all, but a parenchymatous mass homologous with the pith. The superficial meristematic layer can add no units of constmuction to the shoot; the floral parts are simply emergences from it with no axial founda- tion such as is present with a leaf primordium. Not even the sepals are regarded now, in contradistinction to Grégoire's earlier views, as homologues of foliar structures.

The insertion of each new foliar primordium becomes the centre of a new impetus to procambial activity, the leaf-trace system of the new unit thus contributing basifugally to the vascular tracts spreading into the leaf and basipetally to the trace system linking this with the axis. In the reproductive axis, this basipetal contribution to procambial development is missing ; from a procambial 'magma' often of considerable extent and sometimes spread solidly across the base of the reproductive axis, cordons of procambium, often anastomosing or bifurcating freely, spread basifugally into peduncles and then into floral parts; but there is no suggestion that this procambial activity contributes basipetally to an enlargement of the vascular system bolow the reproductive axis.

The two types of growth, the vegetative and reproductive, are fundamentally distinct and not reducible to a common plan. A reproductive apex does not even develop out of a vegetative apex by its gradual modification; it arises as a lateral growth on the side of the vegetative apex that it displaces, and if subsequent proliferation shows a return to foliar emergences then a vegetative apex has re-arisen adventively on a reproductive axis. Such a reproductive axis, always a layer of meristem tissue upon a parenchymatous plinth, still capable of some growth and extension (the porte-méristème of Grégoire) may be used up entirely in the production of floral parts, it may dichotomize by the development of a central groove, or divide into more fragments as the result of moro grooves developing. Its floral members arise without plastochronic intervals and theso members are local products of a portion of the meristom without the tendency to bilateral spread around the axis characteristic of the foliar primordium.

Grégoire distinguishes two types of carpels among those now described: the Ranunculus type, in which a 